\title{
Hubungan Pengetahuan Plebitis dengan Keterampilan Tenaga Kesehatan dalam Menerapkan Problem Solving for Better Health pada Plebitis di Rumah Sakit X
}

\author{
Yuhelma, Yulastri Arif ${ }^{2}$, Leni Merdawati²
}

\begin{abstract}
Abstrak
Problem Solving for Better Health (PSBH) diterapkan di Rumah Sakit X (RS X) untuk mengatasi masalah plebitis di ruang IGD, ruang Interne, dan ruang Paru-Syaraf sebagai ruang pilot project. Penerapan PSBH belum optimal, karena masih ada tenaga kesehatan yang tidak mampu menghasilkan Plan of Action (PoA) untuk mengatasi masalah phlebitis. Ada juga yang sudah menghasilkan PoA, namun belum maksimal dalam implementasinya. Kondisi seperti ini mengakibatkan belum ada penurunan angka plebitis secara signifikan. Tujuan: Menentukan hubungan pengetahuan plebitis dengan keterampilan tenaga kesehatan dalam menerapkan PSBH pada plebitis. Metode: Desain penelitian ini adalah analitik dengan pendekatan cross sectional. Jumlah sampel yang digunakan sebanyak 31 orang dengan teknik purposive sampling. Uji statistik menggunakan Chi-square test. Hasil: Karakteristik tenaga kesehatan di RS X hampir keseluruhan berusia dewasa $83,3 \%$, sebagian besar perempuan $74,2 \%$, berpendidikan profesional $61,3 \%$, dan lama kerja $\geq 5$ tahun $74,2 \%$, ada hubungan yang bermakna antara pengetahuan phlebitis dengan keterampilan PSBH pada plebitis dengan nilai $p<0,05$. Simpulan: ada hubungan yang signifikan antara pengetahuan plebitis dengan keterampilan tenaga kesehatan dalam menerapkan PSBH pada plebitis.
\end{abstract}

Kata kunci: plebitis, PSBH, pengetahuan, keterampilan

\begin{abstract}
Problem Solving for Better Health (PSBH)was implemented in X Hospital to overcome phlebitis in the emergency room, interne room, and lungs-nerve room as a pilot project room. The application of PSBH had not been optimal, because there are still health workers who are unable to produce Plan of Action (PoA) to overcome phlebitis. Health workers who have produced PoA, but it has not been maximized in its implementation. Its conditions have resulted unsignificant reduction in the number of phlebitis. Objectives: To determined the relationship of knowledge andh the skills of health workers in applying PSBH to phlebitis. Methods: This was a analytic research design with cross sectional approach. The number of sample is 31 people with technic purposive sampling. Statistic used Chisquare test. Results: The characteristics of health workers in X Hospital were almost adults aged 83.3\%, mostly women $74.2 \%$, professional educated $61.3 \%$, and length of work $\geq 5$ years $74.2 \%$, there was a significant relationship between knowledge phlebitis with PSBH skills on plebitis with $p$ value $<0.05$. Conclusion: There is a significant relationship between phlebitis knowledge and skills of health workers in applying PSBH to plebitis.
\end{abstract}

Keywords: phlebitis, PSBH, knowledge, skills

Affiliasi penulis: 1. Rumah Sakit Umum Daerah Solok Selatan, 2. Fakultas Keperawatan, Universitas Andalas, Padang, Indonesia. Korespondensi:Yuhelma. Email: yuhelmayuhelma@yahoo.com. Telp: 081365695699

\section{PENDAHULUAN}

Plebitis merupakan salah satu masalah kesehatan yang terjadi di berbagai negara di dunia termasuk Indonesia. Plebitis merupakan komplikasi yang sering terjadi pada pasien yang mendapatkan 
terapi intravena dengan karakteristik adanya merah, seperti terbakar, bengkak, sakit bila ditekan, ulkus sampai eksudat purulen atau mengeluarkan cairan bila ditekan. ${ }^{1,2}$

Plebitis disebabkan oleh berbagai faktor antara lain usia, cairan infus, antibiotik, penyakit penyerta seperti diabetes mellitus, kanker, hipertensi, dan gagal ginjal, teknik pemasangan infus yang tidak sesuai prosedur, lamanya pemasangan infus ikut berperan terhadap kejadian plebitis. ${ }^{3,4}$

Di Indonesia prevalensi kejadian plebitis beragam. Angka kejadian plebitis di Indonesia sebesar 50,11\% untuk RS Pemerintah, sedangkan untuk RS Swasta sebesar $32,70 .{ }^{5}$ Kejadian plebitis yang menjadi permasalahan global menunjukkan angka melebihi angka standar yang ditetapkan yaitu standar nasional $\leq 1,5 \%$ atau $1 \%$. Hal ini membawa dampak buruk pada pasien yang dirawat dan juga bagi institusi rumah sakit itu sendiri. ${ }^{6}$

Salah satu upaya mencegah terjadinya plebitis dapat dilakukan dengan inovasi dan kreatifitas.Upaya ini membutuhkan sumber daya manusia yang peduli serta mampu menciptakan ide-ide kreatif dan inovatif, sehingga ide tersebut dapat digunakan sebagai salah satu metode pemecahan masalah yang ada. ${ }^{7}$

Problem Solving for Better Health (PSBH) adalah suatu metode penyelesaian masalah yang terdiri dari lima langkah kerangka kerja dengan menggunakan sumber daya yang ada, praktis, inovatif, dan mudah untuk dilaksanakan. ${ }^{8}$ Oleh karena masalah plebitis merupakan salah satu masalah kesehatan yang perlu mendapat penanganan serius dan butuh kepedulian tenaga kesehatan, maka metode $\mathrm{PSBH}$ dapat digunakan untuk mengatasi masalah tersebut.

Rumah Sakit X telah menerapkan PSBH di tiga ruangan pilot project yaitu ruang IGD, Interne dan Paru Syaraf. Penerapan PSBH terutama pada kasus plebitis. Hasil observasi terlihat penerapan PSBH belum optimal dimana masih ada tenaga kesehatan yang tidak mampu menghasilkan Plan of Action (PoA) dan ada juga yang sudah mampu menghasilkan PoA, namun belum maksimal dalam implementasinya, sehingga kejadian plebitis tidak berkurang secara signifikan. Studi pendahuluan dilapangan yang peneliti dapatkan dari Laporan Infection Prevention Control Nurse (IPCN) di bulan Juni 2019 di RS X bahwa kejadian plebitis di ruang Interne sebesar 53,94\% dan ruang Paru-Syaraf sebesar 68,57\%. Penerapan PSBH tidak lepas dari penguasaan ilmu tentang plebitis secara luas. Penelitian ini akan melihat hubungan pengetahuan plebitis dengan keterampilan tenaga kesehatan dalam menerapkan PSBH pada plebitis.

\section{METODE}

Jenis penelitian ini adalah penelitian kuantitatif menggunakan desain deskriptif analitik dengan pendekatan cross sectional yang bertujuan untuk mengetahui hubungan pengetahuan plebitis dengan keterampilan tenaga kesehatan dalam menerapkan PSBH pada plebitis.

Populasi dalam penelitian ini dibatasi oleh ruang yang digunakan sebagai pilot project sesuai kriteria pelaksanaan PSBH, dimana penerapan PSBH lebih efektif pada kelompok kecil dengan jumlah $\leq 10$ orang dan observasi evaluasi berkesinambungan. Populasi dalam penelitian ini berjumlah 34 orang terdiri dari tenaga kesehatan meliputi kepala seksi keperawatan berjumlah 1 orang, IPCN berjumlah 1 orang, dokter berjumlah 8 orang, perawat berjumlah 21 orang (professional dan vokasional), dan petugas apotek di ruang Instalasi Gawat Darurat, ruang Interne, ruang Paru-Syaraf berjumlah 3 orang.

Teknik pengambilan sampel dalam penelitian ini digunakan purposive sampling, sehingga populasi yang sesuai dengan kriteria berjumlah 31 orang. Adapun kriteria inklusi sampel dalam penelitian ini adalah; pendidikan minimal $S 1$, sudah pernah mengikuti sosialisasi $\mathrm{PSBH}$, pengalaman kerja $\geq 3$ tahun, mampu berkomunikasi dan bekerjasama dengan baik, bersedia menjadi responden.

Penelitian ini dilakukan di tiga ruangan yang ditetapkan sebagai pilot project untuk penerapan metode PSBH antara lain ruang IGD, ruang Interne dan ruang Paru-Syaraf $\mathrm{RS} X$. Ketiga ruangan ini sebagai pilot project dikarenakan persentase kejadian plebitis tertinggi di RS $X$ adalah ruang Paru-Syaraf $(68,57 \%)$ dan ruang Interne (53,94\%) serta pemasangan infus sebagian besar di ruang IGD.

Pengumpulan data dilakukan semenjak 3 Juli sampai dengan 7 Juli 2019. Alat pengumpul data yang digunakan dalam penelitian ini adalah; 1) kuesioner 
pengetahuan tentang plebitis yang terdiri dari 8 item pertanyaan plebitis. 2) lembar observasi keterampilan menerapkan $\mathrm{PSBH}$ yang diadopsi dari teori lima tahap metode PSBH dengan jumlah total 26 item pernyataan dengan rincian yaitu; identifikasi masalah (4 pernyataan), prioritas masalah (5 pernyataan), solusi masalah (8 pernyataan), penyusunan Plan of Action (PoA) (6 pernyataan), dan implementasi (action) PoA (3 pernyataan). Uji statistik menggunakan Chi-Square test.

HASIL

Tabel 1.Karakteristik tenaga kesehatan

\begin{tabular}{llcc}
\hline No & \multicolumn{1}{c}{ Karakteristik } & $\mathbf{f}$ & $\%$ \\
\hline 1. & Jeniskelamin & 23 & 74,2 \\
& Perempuan & 8 & 25,8 \\
& Laki-laki & & \\
2. & Usia & 26 & 83,9 \\
& Dewasa & 5 & 16,1 \\
& Lansia & & \\
& & & \\
3. & Pendidikan & 19 & 61,3 \\
& Profesi & 12 & 38,7 \\
& Sarjana & & \\
4. & MasaKerja & 8 & 25,8 \\
& $<5$ tahun & 23 & 74,2 \\
\hline
\end{tabular}

Berdasarkan Tabel 1 dapat dilihat sebagian besar tenaga kesehatan adalah perempuan, berpendidikan, profesi, dan memiliki masa kerja $\geq 5$ tahun. Hampir keseluruhan tenaga kesehatan berusia dewasa.

Tabel 2. Pengetahuan plebitistenaga kesehatan

\begin{tabular}{lcc}
\hline Pengetahuan Plebitis & f & $\%$ \\
\hline Tinggi & 18 & 58,1 \\
Rendah & 13 & 41,9 \\
\hline
\end{tabular}

Berdasarkan table sebagian besar tenaga kesehatan memiliki pengetahuan tinggi tentang plebitis.
Tabel 3. Keterampilan PSBH tenaga kesehatan

\begin{tabular}{llrr}
\hline No & \multicolumn{1}{c}{ Keterampilan PSBH } & $\mathbf{f}$ & $\%$ \\
\hline 1. & Identifikasi masalah & 20 & 64,5 \\
& Baik & 11 & 35,5 \\
& Kurang baik & & \\
2. & Prioritas masalah & 16 & 51,6 \\
& Baik & 15 & 48,8 \\
& Kurang baik & & \\
3. & Solusi masalah & 12 & 38,7 \\
& Baik & 19 & 61,3 \\
& Kurang baik & & \\
4. & Penyusunan PoA & 14 & 45,2 \\
& Baik & 17 & 54,8 \\
Kurang baik & Implementasi PoA & 12 & 38,7 \\
& Baik & 19 & 61,3 \\
5urangbaik & Total Keterampilan PSBH & & \\
Baik & 12 & 38,7 \\
& Kurangbaik & 19 & 61,3 \\
\hline
\end{tabular}

Berdasarkan Tabel 3 sebagian besar tenaga kesehatan terampil dalam menerapkan identifikasi masalah, dan memprioritaskan masalah. Sedangkan untuk keterampilan menerapkan solusi masalah, penyusunan PoA, implementasi PoA sebagian besar masih kurang baik. Total keterampilan PSBH sebagian besar kurang baik.

Tabel 4. Hubungan pengetahuan plebitis dengan keterampilan problem solver for better health (PSBH) pada plebitis

\begin{tabular}{|c|c|c|c|c|c|c|}
\hline \multirow{3}{*}{$\begin{array}{l}\text { Pengetahuan } \\
\text { Plebitis }\end{array}$} & \multicolumn{4}{|c|}{ Total Keterampilan PSBH } & \multirow{3}{*}{ p } & \multirow{3}{*}{$\begin{array}{c}\text { OR } \\
(95 \% \mathrm{Cl})\end{array}$} \\
\hline & \multicolumn{2}{|c|}{ Baik } & \multicolumn{2}{|c|}{ Kurang baik } & & \\
\hline & $f$ & $\%$ & f & $\%$ & & \\
\hline Plebitis & & & & & & 18,857 \\
\hline Tinggi & 11 & 61,1 & 7 & 38,9 & 0,008 & $(1,98-$ \\
\hline Rendah & 1 & 7,7 & 12 & 92,3 & & $178,79)$ \\
\hline
\end{tabular}

Berdasarkan Tabel 4 terlihat ada hubungan antara pengetahuan plebitis dengan keterampilan PSBH dengan $p=0,008$. Uji statistik didapatkan nilai 
OR 18,857, artinya pengetahuan tinggi tentang plebitis berpeluang 18 kali untuk memiliki keterampilan baik dibanding pengetahuan plebitis rendah.

Tabel 5. Hubungan pengetahuan plebitis dengan item identifikasi masalah

\begin{tabular}{lrrrrrr}
\hline & \multicolumn{9}{c}{ Item Identifikasi Masalah } & & \\
\cline { 2 - 5 } $\begin{array}{l}\text { Pengetahuan } \\
\text { Plebitis }\end{array}$ & \multicolumn{2}{c}{ Baik } & \multicolumn{2}{c}{ Kurang baik } & p & $\begin{array}{c}\text { OR } \\
\text { Plebitis }\end{array}$ \\
\cline { 2 - 4 } & $\mathbf{f}$ & $\%$ & $\mathbf{f}$ & $\%$ & & $(95 \% \mathrm{Cl})$ \\
\hline Tinggi & 18 & 100 & 0 & 0,0 & 0,000 & - \\
Rendah & 2 & 15,4 & 11 & 84,6 & & \\
\hline
\end{tabular}

Berdasarkan Tabel 5, terlihat ada hubungan antara pengetahuan plebitis dengan item identifikasi masalah dengan nilai $p=0,000$. Uji statistik didapat nilai OR (-), artinya tidak dapat dibandingkan keterampilan mengidentifikasi masalah antara tenaga kesehatan yang berpengetahuan plebitis tinggi dengan yang rendah.

Tabel 6. Hubungan pengetahuan plebitis dengan item prioritas masalah

\begin{tabular}{|c|c|c|c|c|c|c|}
\hline \multirow{3}{*}{$\begin{array}{l}\text { Pengetahuan } \\
\text { Plebitis }\end{array}$} & \multicolumn{4}{|c|}{ Item Prioritas Masalah } & \multirow{3}{*}{$\mathbf{p}$} & \multirow{3}{*}{$\begin{array}{c}\text { OR } \\
(95 \% \mathrm{Cl})\end{array}$} \\
\hline & \multicolumn{2}{|c|}{ Baik } & \multicolumn{2}{|c|}{ Kurang baik } & & \\
\hline & $f$ & $\%$ & $f$ & $\%$ & & \\
\hline \multicolumn{7}{|l|}{ Plebitis } \\
\hline Tinggi & 15 & 83,3 & 3 & 16,7 & 0,000 & 60,000 \\
\hline \multirow[t]{2}{*}{ Rendah } & 1 & 7,7 & 12 & 92,3 & & $(5,51-$ \\
\hline & & & & & & $652,90)$ \\
\hline
\end{tabular}

Berdasarkan Tabel 6, ada hubungan antara pengetahuan plebitis dengan item prioritas masalah dengan $p=0,000$. Uji statistik didapat nilai OR $(60,000)$, artinya tenaga kesehatan berpengetahuan tinggi tentang plebitis berpeluang 60 kali lebih terampil memprioritaskan masalah dibanding tenaga kesehatan yang berpengetahuan plebitis rendah.

Tabel 7. Hubungan pengetahuan plebitis dengan item solusi masalah

\begin{tabular}{|c|c|c|c|c|c|c|}
\hline \multirow{3}{*}{$\begin{array}{l}\text { Pengetahuan } \\
\text { Plebitis }\end{array}$} & \multicolumn{4}{|c|}{ Item Solusi Masalah } & \multirow{3}{*}{$\mathbf{p}$} & \multirow{3}{*}{$\begin{array}{c}\text { OR } \\
(95 \% \mathrm{Cl})\end{array}$} \\
\hline & \multicolumn{2}{|c|}{ Baik } & \multicolumn{2}{|c|}{ Kurang baik } & & \\
\hline & $f$ & $\%$ & $f$ & $\%$ & & \\
\hline \multicolumn{7}{|l|}{ Plebitis } \\
\hline Tinggi & 11 & 61,1 & 7 & 38,9 & 0,008 & 18,857 \\
\hline \multirow[t]{2}{*}{ Rendah } & 1 & 7,7 & 12 & 92,3 & & $(1,98-$ \\
\hline & & & & & & $178,79)$ \\
\hline
\end{tabular}

Berdasarkan Tabel 7, terlihat ada hubungan antara pengetahuan plebitis dengan item solusi masalah dengan $p=0,008$. Uji statistik didapat nilai OR $(18,857)$, artinya tenaga kesehatan berpengetahuan tinggi tentang plebitis berpeluang 18 kali lebih terampil membuat solusi masalah dibanding tenaga kesehatan yang berpengetahuan plebitis rendah.

Tabel 8. Hubungan pengetahuan plebitis dengan item penyusunan $\mathrm{PoA}$

\begin{tabular}{lccccccc}
\hline \multirow{2}{*}{$\begin{array}{l}\text { Pengetahuan } \\
\text { Plebitis }\end{array}$} & \multicolumn{9}{c}{ Item Penyusunan PoA } & & \multirow{2}{c}{ Kaik } & \multicolumn{2}{c}{ Kurang baik } & $\mathbf{p}$ & OR \\
\cline { 2 - 5 } & $\mathbf{f}$ & $\%$ & $\mathbf{f}$ & $\%$ & & $(95 \% \mathrm{Cl})$ \\
\hline Plebitis & 12 & 66,7 & 6 & 33,3 & 0,014 & 11,000 \\
Tinggi & 1 & 15,4 & 11 & 84,6 & & $(1,82-$ \\
Rendah & & & & & & $66,36)$ \\
& & & & & &
\end{tabular}

Berdasarkan tabel ada hubungan antara pengetahuan plebitis dengan item penyusunan PoA dengan $p=$ 0,014 . Uji statistik didapat nilai OR $(11,000)$, artinya tenaga kesehatan berpengetahuan tinggi tentang plebitis berpeluang 11 kali lebih terampil dalam menyusun PoA dibanding tenaga kesehatan yang berpengetahuan plebitis rendah.

Tabel 9. Hubungan pengetahuan plebitis dengan item implementasi PoA

\begin{tabular}{|c|c|c|c|c|c|c|}
\hline \multirow{3}{*}{$\begin{array}{l}\text { Pengetahuan } \\
\text { Plebitis }\end{array}$} & \multicolumn{4}{|c|}{ Item Implementasi PoA } & \multirow{3}{*}{$\mathbf{p}$} & \multirow{3}{*}{$\begin{array}{c}\text { OR } \\
(95 \% \mathrm{Cl})\end{array}$} \\
\hline & \multicolumn{2}{|c|}{ Baik } & \multicolumn{2}{|c|}{ Kurang baik } & & \\
\hline & $f$ & $\%$ & $f$ & $\%$ & & \\
\hline \multicolumn{7}{|l|}{ Plebitis } \\
\hline Tinggi & 11 & 61,1 & 7 & 38,9 & 0,008 & 18,857 \\
\hline \multirow[t]{2}{*}{ Rendah } & 1 & 7,7 & 12 & 92,3 & & $(1,98-$ \\
\hline & & & & & & $178,79)$ \\
\hline
\end{tabular}

Berdasarkan Tabel 9, ada hubungan antara pengetahuan plebitis dengan item implementasi PoA dengan $p=0,008$. Uji statistik didapat nilai OR $(18,857)$, artinya tenaga kesehatan berpengetahuan tinggi tentang plebitis berpeluang 18 kali lebih terampil implementasi PoA dibanding tenaga kesehatan yang berpengetahuan plebitis rendah. 


\section{PEMBAHASAN}

Hasil penelitian menunjukkan dari 18 orang tenaga kesehatan berpengetahuan tinggi tentang plebitis terdapat $(61,1 \%)$ memiliki keterampilan $\mathrm{PSBH}$ baik dan (38,9\%) memiliki keterampilan PSBH kurang baik. Terdapat hubungan pengetahuan plebitis dengan keterampilan $\mathrm{PSBH}$ dengan $\mathrm{p}=0,008$, artinya semakin tinggi pengetahuan tentang plebitis, maka akan semakin baik keterampilan PSBH masalah plebitis. Tenaga kesehatan yang berpengetahuan tinggi tentang plebitis berpeluang $18 \mathrm{kali}$ lebih terampil dalam menerapkan PSBH dibanding tenaga kesehatan berpengetahuan plebitis rendah.

Penelitian hampir sama oleh Riris dan Kuntarti (2014) di RS X mendapatkan hasil dimana terdapat hubungan pengetahuan tentang terapi intravena dengan praktik pencegahan plebitis bacterial dengan $p=0,001 .{ }^{9} \mathrm{Hal}$ ini dikarenakan sebagian besar tenaga kesehatan pernah mengikuti pelatihan intravena, sehingga lebih terampil dalam pemasangan infus. Wayunah et al (2013) di RS Y mengungkapkan hal yang hampir sama dimana terdapat hubungan pengetahuan tentang terapi infus dengan kejadian plebitis dengan nilai $p=0,000$. Penelitian ini mengungkapkan bahwa tenaga kesehatan kurang terampil dalam pemasangan infus yang berakibat terjadinya plebitis dikarenakan kurang menguasai pengetahuan tentang pemasangan infus dan plebitis. ${ }^{10}$

Keterampilan merupakan aplikasi dari pengetahuan. Untuk dapat memiliki keterampilan yang baik, maka perlu mengaplikasikan pengetahuan yang dimiliki dengan tindakan nyata. Semakin baik pengetahuan, maka akan semakin baik pula kemampuan teknikal. ${ }^{11,12}$

Pada penelitian ini diketahui pula item keterampilan $\mathrm{PSBH}$ tenaga kesehatan yaitu pada tahap identifikasi masalah, dimana seluruh tenaga kesehatan (100\%) yang berpengetahuan tinggi tentang plebitis lebih terampil menerapkan PSBH. Hal ini dipengaruhi faktor pengetahuan plebitis yang cukup dari hasil pelatihan dan workshop. Faktor lain adalah minat dan motivasi tinggi untuk ingin tahu tahap PSBH. Sesuai ungkapan Purwoastuti dan Walyani (2015), salah satu faktor yang mempengaruhi keterampilan seseorang adalah faktor internal yaitu minat dan motivasi individu untuk belajar dan berlatih. ${ }^{13}$

Pada tahap prioritas masalah terdapat penurunan sebagian kecil (16,7\%) kurang terampil menerapkan PSBH. Hal ini disebabkan kurang memahami metode penentuan prioritas masalah yang dijadikan sebagai acuan yaitu teknik skoring dengan metode PAHO (Pan American Health Organization). Penentuan prioritas masalah dapat dilakukan secara kualitatif (Non Scoring) seperti metode Delbeg atau Delphi dan secara kuantitatif (scoring) seperti metode Bryant, PAHO, Hanlon, CARL, dan Reinke. Prioritas masalah dilakukan oleh sekelompok orang dengan metode tertentu yang dipilih dan disepakati. ${ }^{14}$

Pada tahap solusi masalah kembali terjadi penurunan hampir separoh (38,9\%) kurang terampil menerapkan PSBH. Hal ini disebabkan kurang pengetahuan dan wawasan tentang plebitis lebih luas termasuk tentang terapi infus, sehingga kurang mampu memunculkan ide-ide kreatif untuk solusi masalah yang kemudian berpengaruh pada penyusunan PoA. PSBH membutuhkan pengetahuan yang tinggi tentang masalah yang akan dicari solusinya, sehingga menjadi dasar timbulnya ide-ide kreatif untuk solusi masalah sesuai sumber daya yang ada. $^{15}$

Pada tahap penyusunan PoA terjadi penurunan $(33,3 \%)$ kurang terampil menerapkan PSBH. Hal ini disebabkan faktor accidental (kebetulan) 5.6\% dapat melengkapi target kegiatan yang ingin dicapai dalam PoA. Hal ini terbukti pada tahap implementasi PoA hampir separoh $(38,9 \%)$ kembali kurang terampil menerapkan PSBH. Artinya, kurang terampil dalam tahap awal $\mathrm{PSBH}$, maka akan berpengaruh sampai tahap akhir PSBH. Hal ini dikarenakan $\mathrm{PSBH}$ merupakan metode penyelesaian masalah skala kecil yang sederhana, butuh pengetahuan yang tinggi terhadap masalah, inovatif dan sistematis berupa lima kerangka kerja yaitu identifikasi masalah, prioritas masalah, solusi masalah, penyusunan PoA, dan implementasi PoA. ${ }^{16}$

Faktor lain yang peneliti temukan sebagai penyebab kurang terampil penerapan $\mathrm{PSBH}$ tenaga kesehatan adalah faktor manajemen yang belum melakukan upaya tindak lanjut untuk mempertahankan 
bahkan meningkatkan pengetahuan dan keterampilan $\mathrm{PSBH}$ setelah dilaksanakan pelatihan dan workshop $\mathrm{PSBH}$. Oleh karena itu diharapkan bagi tenaga kesehatan yang mempunyai minat dan motivasi tinggi untuk menerapkan PSBH dapat lebih membuka wawasan ilmu pengetahuan terkait masalah yang akan diselesaikan secara mandiri melalui media internet atau liteatur lainnya. Tenaga kesehatan diharapkan lebih proaktif untuk berlatih menerapkan PSBH sebagai upaya mencari solusi masalah plebitis ataupun masalah lainnya di lingkungan kerja seperti melakukan bedah kasus plebitis. Untuk manajemen rumah sakit diharapkan memiliki komitmen dan melakukan supervisi penerapan $\mathrm{PSBH}$ sebagai motivasi belajar dan berlatih bagi tenaga kesehatan.

\section{SIMPULAN}

Ada hubungan yang bermakna antara pengetahuan plebitis dengan ketrampilan tenaga kesehatan dalam menerapkan PSBH. Hal ini berarti semakin tinggi pengetahuan tentang konsep plebitis, maka keterampilan tenaga kesehatan dalam menerapkan PSBH pada plebitis akan lebih baik.

\section{SARAN}

Manajemen rumah sakit diharapkan dapat mengembangkan pengetahuan dan keterampilan PSBH tenaga kesehatan dengan memberikan pendidikan dan pelatihan terkait terapi infus dan plebitis, melaksanakan supervisi terjadwal tentang pemasangan infus dan meningkatkan latihan penerapan $\mathrm{PSBH}$ pada plebitis, serta monitor evaluasi penerapan $\mathrm{PSBH}$ di ruangan pilot project.

\section{UCAPAN TERIMA KASIH}

Ucapan terima kasih peneliti kepada semua pihak yang terkait yang berkontibusi pada kesempurnaan penelitian ini. Harapan peneliti semoga hasil penelitian ini bermanfaat bagi banyak orang.

\section{DAFTAR PUSTAKA}

1. Nursalam. Manajemen keperawatan aplikasi dalam praktek keperawatan profesional. Jakarta. Salemba Medika. 2016.hlm.119-23.
2. Komisi Akreditasi Rumah Sakit (KARS). Standar nasional akreditasi RS. Jakarta. Kemenkes RI. 2017.hlm.223-5.

3. Salguiro A, Veigo P, Parreira P. Incidence of phlebitis in patients with peripheral intravenous catheters: the influence of some risk factors. Australian Journal Advance Nurse. 2010; 30(2): 32-9.

4. Rizky W. Analisis faktor yang berhubungan dengan kejadian plebitis pada pasien yang terpasang kateter intravena di ruang bedah rumah sakit Ar Bunda Pramulih. Jurnal Ners dan Kebidanan Indonesia. 2016;4(2):102-8.

5. Kementerian Kesehatan RI (Kemenkes RI). Standar pelayanan minimal RS. Jakarta. Kemenkes RI. 2008.hlm.46-51.

6. Kemenkes RI. Pedoman pencegahan dan pengendalian infeksi. Jakarta. Kemenkes RI. 2017.hlm.40-6.

7. Thanh N, Thi N, Mai T. Service quality and its impact on patient satisfaction: an investigation in Vietnamese public hospitals. Journal of Emerging Economies and Islamic Research. 2013; 2 (1): $1-13$

8. Smith B, Barnett S, Callado D, Connor M. Problem solving for better health. World Health Forum. 1994;15(1):9-15.

9. Riris E, Kuntarti. Pengetahuan tentang terapi intravena berhubungan dengan perilaku perawat dalam pencegahan flebitis. Jurnal Keperawatan Indonesia. 2014;17(3):108-18.

10. Wayunah, Nurachmah E, Mulyono S. Pengetahuan perawat tentang terapi infus mempengaruhi kejadian plebitis dan kenyamanan pasien. Jurnal Keperawatan Indonesia. 2013;16(2):128-37.

11. Martanti R, Nofiyanto M, Prasojo A. Hubungan tingkat pengetahuan dengan keterampilan petugas dalam pelaksanaan triage di instalasi gawat darurat di RSUD Wates. Media IImu Kesehatan. 2015; 4(2): 69-76.

12. GhofarA, Subeqi MI. Hubungan antara pengetahuan dan sikap perawat dengan kemampuan teknikal perawat dalam pelaksanaan oral hygiene pada penderita stroke. Jurnal Edu Health.2015;5(1): 28-38 
13. Purwoastuti E, Walyani ES. Perilaku \& softskills kesehatan. Yogyakarta. Pustaka Baru Press. 2015.hlm. 21-3

14. Yuliastuti K. Pengaruh penerapan metode problem solving for better health (PSBH) terhadap pengembangan proaktifitas perawat pelaksana dan proaktifitas dalam melaksanakan operan pasien di RSUD Tugurejo Semarang [tesis]. Jakarta: Fakultas Keperawatan Universitas Indonesia; 2009.hIm.113
15. Hoyt P. An International Approach to problem solving for better health nursing TM( PSBHN ). Journal Compilation. 2007; 54(1):100-6.

16. Hoyt $P$. Problem solving for better health nursing a working approach to the development and dissemination of applied research in developping countries. Applied Nursing Research. 2006; 19(2):110-2. 